\title{
PENGARUH MODEL PEMBELAJARAN TREFFINGER BERPENDEKATAN SAINTIFIK TERHADAP KEMAMPUAN BERPIKIR KREATIF DITINJAU DARI GAYA KOGNITIF SISWA
}

\author{
N.P. Cipta Wardani, Sariyasa, A.A.I.N. Marhaeni \\ Program Studi Pendidikan Dasar, Program Pascasarjana \\ Universitas Pendidikan Ganesha \\ Singaraja, Indonesia
}

e-mail: \{cipta.wardani, sariyasa agung.marheini\}@pasca.undiksha.ac.id

\begin{abstract}
Abstrak
Penelitian ini bertujuan untuk mengetahui pengaruh model pembelajaran treffinger berpendekatan saintifik terhadap kemampuan berpikir kreatif ditinjau dari gaya kognitif siswa. Penelitian ini merupakan eksperimen semu dengan rancangan faktorial $2 \times 2$. Populasi adalah seluruh kelas V SD yang ada di Gugus II Kecamatan Kintamani yang berjumlah 221 siswa. Sampel penelitian terdiri dari dua kelas eksperimen dan dua kelas kontrol yang dipilih dengan teknik random sampling dengan jumlah 68 siswa. Data kemampuan berpikir kreatif dan gaya kognitif dikumpulkan menggunakan tes. Data dianalisis dengan menggunakan ANAVA dua jalan berbantuan SPSS 17.00 for windows. Hasil penelitian menunjukkan bahwa: Pertama, terdapat perbedaan kemampuan berpikir kreatif antara kelompok siswa yang mengikuti pembelajaran menggunakan model pembelajaran treffinger berpendekatan saintifik dan kelompok siswa yang mengikuti pembelajaran dengan model konvensional. Kedua, terdapat interaksi antara model pembelajaran dan gaya kognitif siswa terhadap kemampuan berpikir kreatif. Ketiga, pada siswa yang memiliki gaya kognitif Field Independent $(F I)$, terdapat perbedaan kemampuan berpikir kreatif antara kelompok siswa yang mengikuti pembelajaran menggunakan model pembelajaran treffinger berpendekatan saintifik dan kelompok siswa yang mengikuti pembelajaran dengan model konvensional. Kempat, pada siswa yang memiliki gaya kognitif Field Dependent (FD), terdapat perbedaan kemampuan berpikir kreatif antara kelompok siswa yang mengikuti pembelajaran menggunakan model pembelajaran treffinger berpendekatan saintifik dan kelompok siswa yang mengikuti pembelajaran konvensional.
\end{abstract}

Kata kunci: gaya kognitif, kemampuan berpikir kreatif, model treffinger, pendekatan saintifik

\begin{abstract}
This study aims to determine the effect of treffinger learning models with scientific approach to creative thinking skills in terms of students' cognitive styles. This type of research is a quasi-experimental study with design with a $2 \times 2$ factorial design. The population used was all class V elementary schools in Group II of Kintamani Subdistrict totaling 221 students. The research sample consisted of two experimental classes and two control classes were chosen by random sampling technique with 68 students. Data on creative thinking and cognitive styles are collected using a test. Data were analyzed using analysis of two-way Anava assisted SPSS 17.00 for windows. The results showed that: First, there differences in creative thinking skills between groups of students who took part in learning using the Treffinger learning model with scientific approach and groups of students who followed learning with conventional models. Second, there interaction between the learning model and the cognitive style of students towards the ability to think creatively. Third, for students who have the Field Independent (FI) cognitive style, there differences in creative thinking skills between groups of students who take part in learning using the Treffinger learning model with scientific approach and groups of students who follow learning with conventional models. Fourth, in students who have a Field Dependent (FD) cognitive style, differences in creative thinking skills between groups of students who take part in learning using the Treffinger learning model with scientific approach and groups of students who follow learning with conventional models.
\end{abstract}

Keywords: ability to think creatively, cognitive style, model treffinger, scientific approach 


\section{PENDAHULUAN}

Guru sebagai pendidik berkewajiban untuk mengondisikan pembelajaran agar siswa mampu mengembangkan kecerdasan dan kemampuan berpikir kreatif. Kewajiban ini diemban oleh para pendidik karena pendidik dan siswa hidup dalam suatu kondisi demokratis yang sangat menghargai nalar dan berpikir secara kreatif. Mengingat pentingnya melatih berpikir kreatif pada siswa, guru seharusnya memberikan perhatian pada kemampuan tersebut selama proses pembelajaran. Melalui berpikir kreatif, siswa diajak berperan serta secara aktif dan efektif untuk membangun pengetahuannya sendiri. Berpikir kreatif tidak dapat diajarkan melalui pembelajaran yang hanya menekankan pada teacher center karena berpikir kreatif merupakan proses aktif. Kemampuan intelektual dari berpikir kreatif mencakup berpikir lancar, berpikir luwes, berpikir orisinal, dan berpikir memerinci (Boesen, 2006) yang harus dipelajari melalui aktualisasi penampilan (performance).

Berdasarkan hasil observasi awal dapat diketahui kondisi pembelajaran yang ada pada saat ini justru sebaliknya, yaitu pengelolaan pembelajaran untuk meningkatkan kemampuan berpikir kreatif siswa belum ditangani secara optimal. Guru mengajar hanya menyampaikan materi yang terdapat di buku paket dan kurang mengkomudasi kemampuan siswa. Dengan kata lain, guru tidak memberikan kesempatan kepada siswa untuk mengkontruksi pengetahuan matematikanya yang nantinya akan menjadi milik siswa sendiri. Guru cenderung memaksanakan cara berpikir siswa dengan cara berpikir yang dimiliki gurunya. Hal ini menyebab kemampuan berpikir kreatif siswa rendah ini terbukti dari hasil survei yang dilakukan oleh lembaga international salah satunya adalah Progra for International Student Assement (PISA) yang diselenggarakan oleh Organization for Economic Cooperation Development (OECD) pada tahun 2015 menempatkan Indonesia pada posisi 69 dari 76 (Murtiyasa, 2015). Rendahnya kemampuan tersebut diakibatkan dari rendahnya kemampuan berpikir kreatif yang dimiliki oleh siswa (Murtiyasa, 2015).
Hal ini terbukti dari penelitian yang dilakukan oleh Ramandhani dan Nuryanis (2017) yang menunjukan hasil belajar siswa dengan nilai rata-rata yaitu 27,6 dengan Kriteria Ketuntasan Minimal (KKM) sebesar 65. Dari data tersebut nampak bahwa nilai rata-rata yang diperoleh siswa belum mancapai KKM karena selisih nilai siswa dengan KKM yang ditentukan adalah 37,4. Rendahnya hasil belajar siswa dikarenakan kemampuan berpikir kreatif siswa dalam aspek: fluency yaitu menghasilkan ide sebesar 20,5\%, originality yaitu memiliki ide-ide untuk memecah persoalan sebesar $25,7 \%$, dan fleksibilitas yaitu lancar dalam menyelesaikan sebesar 26,6 \%, serta elaboration yaitu kemampuan memerinci suatu masalah sebesar $27,2 \%$.

Berkaitan dengan hal tersebut, permasalah yang sama juga terjadi di gugus II Kecamatan Kintamani melalui argumen guru peneliti menjumpai permasalahan rendahnya kemampuan berpikir kreatif beberapa siswa.Hal tersebut disebabkan karena siswa masih merasa malas untuk mempelajari matematika karena terlalu banyak rumus siswa menganggap bahwa pelajaran matematika adalah pelajaran yang membosankan, siswa masih merasa bingung dalam mengaplikasikan konsep matematika dalam kehidupan sehari-hari, soal matematika yang diberikan sulit untuk dikerjakan. Akibatnya siswa hanya mencontoh apa yang dikerjakan guru, tanpa makna dan pengertian sehingga dalam menyelesaikan soal siswa beranggapan cukup dikerjakan seperti apa yang dicontohkan.

Meningkatkan kemampuan berpikir kreatif matematika dilakukan dengan menciptakan lingkungan yang kondusif bagi perkembangan kemampuan tersebut, sehingga dapat merangsang siswa untuk belajar mandiri, kreatif, dan lebih aktif dalam kegiatan pembelajaran. Salah satu model pembelajaran yang memberi kesempatan kepada siswa untuk meningkatkan kemampuan berpikir kreatif matematika yang baik adalah model 
treffinger. Munandar (2004:172) menyatakan "model Treffinger adalah model yang mendorong belajar kreatif yang secara langsung menangani masalah kreativitas".

Pada tahap model pembelajaran treffinger siswa nantinya akan dihadapkan pada tantangan menyelesaikan permasalahan yang terkait dengan kehidupan siswa dan berhubungan dengan materi pembelajarannya.. Keberhasilan penerapan model pembelajaran treffinger dalam meningkatkan kemampuan berpikir kreatif didukung oleh hasil penelitian yang dilakukan oleh Alfiyanti (2016) yang berjudul "Pengaruh Model Pembelajaran Treffinger Terhadap Kreativitas Matematika Siswa Kelas VII SMP Negeri 1 Poncowarno". Hasil penelitian tersebut menunjukkan bahwa, terdapat perbedaan yang signifikan pada kreativitas matematika antara kelompok siswa yang mengikuti model pembelajaran treffinger dan kelompok siswa yang mengikuti pembelajaran konvensional pada siswa kelas VII VII SMP Negeri 1 Poncowarno. Dengan kata lain terdapat pengaruh positif model pembelajaran treffinger terhadap kreativitas matematika. Hasil penelitian tersebut menjadi bukti bahwa model pembelajaran treffinger sangat tepat diterapkan dalam pembelajaran matematika untuk meningkatkan kemamampuan berpikir kreatif matematika.

Pada penelitian ini model pembelajaran Treffinger dikombinasikan dengan pendekatan saintifik yang sesuai dalam membantu siswa dalam mengkonstruk pemahamannya sendiri serta mengkondisikan siswa agar lebih aktif dalam proses pembelajaran. Model pembelajaran treffinger terdiri dari tiga tahap yaitu basic tool, practice with process, dan working with real problems, yang mana pada tiap tahapan terdapat pendekatan saintifik.

Dalam proses pembelajaran, tidak hanya guru yang berperan sebagai faktor penentu keberhasilan peserta didik, akan tetapi siswa itu sendiri juga menentukan keberhasilan belajarnya. Ada berbagai hal baik dari luar ataupun dari dalam diri peserta didik yang dapat menentukan keberhasilan belajarnya. Salah satu hal yang berpengaruh adalah karakteristik pada diri peserta didik. Setiap siswa memiliki karakteristik yang berbeda antara siswa yang satu dengan yang lainnya. Perbedaan karakteristik tersebut tidak hanya meliputi perbedaan dalam hal sikap, namun juga berbeda dalam cara berpikirnya atau tingkat intelektualnya.

Koefe (dalam Inayah, 2016) menyatakan perbedaan cara seseorang dalam memproses informasi tersebut lebih dikenal dengan istilah gaya kognitif. Candiasa (dalam Novitayanti, 2016) menyatakan bahwa, jenis gaya kognitif seseorang secara sederhana dapat diketahui melalui tindakan atau tingkah laku individu tersebut dalam memilih pendekatan dalam melaksanakan tugas, cara berkomunikasi dalam kehidupan sosial sehari-hari, cara pandang terhadap objek di sekitarnya, mata pelajaran yang cenderung dipilih atau digemari, model pembelajaran yang cenderung dipilih, cara mengorganisir informasi, dan cara berinteraksi dengan guru.

Secara psikologis, gaya kognitif dibedakan menjadi dua, yaitu gaya kognitif Field Independent ( $F I)$ dan Field Dependent (FD). Gaya Kognitif $F I$ menurut Arends (dalam Inayah, 2016) melihat bagian-bagian secara terpisah, memiliki kemampuan analitis kuat dan lebih memantau pemrosesan informasi daripada berhubungan dengan orang lain, sedangkan gaya kognitif $F D$ menganggap situasi secara keseluruhan, melihat gambaran masalah yang paling besar, impersonal, mementingkan hubungan sosial dan bekerja baik dalam kelompok. Berdasarkan hal tersebut gaya kognitif tiap anak yang berbeda menentukan perbedaan kemampuan berpikir kreatif anak dalam pembelajaran matematika.

Berdasarkan permasalah di atas, tujuan penelitian ini adalah untuk mengetahui: (1) perbedaan kemampuan berpikir kreatif antara siswa yang mengikuti model pembelajaran treffinger berpendekatan sainfik dengan siswa yang mengikuti pembelajaran konvensional, (2) 
interaksi antara model pembelajaran dengan gaya kognitif terhadap kemampuan berpikir kreatif, perbedaan terhadap kemampuan berpikir kreatif siswa yang mengikuti model pembelajaran treffinger berpendekatan saintik dengan siswa yang mengikuti pembelajaran konvensional, pada siswa yang memiliki gaya kognitif FI (4) perbedaan perbedaan terhadap kemampuan berpikir kreatif siswa yang mengikuti model pembelajaran treffinger berpendekatan saintifik dengan siswa yang mengikuti siswa yang mengikuti model pembelajaran konvensional. pada siswa yang memiliki gaya kognitif $F D$

\section{METODE}

Penelitian merupakan eksperimen semu dengan rancangan faktorial $2 \times 2$.. Populasi dalam penelitian ini adalah seluruh siswa kelas V di Gugus II Kec. Kintamani berjumlah 221. Sampel terdiri dari dua kelas eksperimen dan dua kelas kontrol yang dipilih dengan teknik random sampling yang berjumlah 68 siswa. Variabel bebas dalam penelitian ini adalah model pembelajaran treffinger berpendektan saintifik dan pembelajaran konvensional, Variabel terikat yaitu kemampuan berpikir kreatif dan variabel moderator adalah gaya kognitif.

Data mengenai kemampuan berpikir kreatif dikumpulkan melalui tes kemampuan berpikir kreatif yang sesuai dengan kisi-kisi yang disusun. Tes tersebut berbentuk pilihan uraian (esai). Data mengenai gaya kognitif dikumpulkan menggunakan tes standar yaitu GEFT (Group Embedded Figure Test).

Uji statistik yang digunakan untuk pengujian hipotesis dalam penelitian ini adalah ANAVA dua jalan dan uji tukey. Hipotesis yang dianalisis pada penelitian ini, yaitu (1) terdapat perbedaan kemampuan berpikir kreatif antara kelompok siswa yang mengikuti pembelajaran menggunakan model pembelajaran treffinger berpendekatan saintifik dan kelompok siswa yang mengikuti pembelajaran dengan model konvensional. (2) terdapat interaksi antara model pembelajaran dan gaya kognitif siswa terhadap kemampuan berpikir kreatif. (3) pada siswa yang memiliki gaya kognitif $F I$, terdapat perbedaan kemampuan berpikir kreatif antara kelompok siswa yang mengikuti pembelajaran menggunakan model pembelajaran treffinger berpendekatan saintifik dan kelompok siswa yang mengikuti pembelajaran dengan model konvensional. (4) pada siswa yang memiliki gaya kognitif $F D$, terdapat perbedaan kemampuan berpikir kreatif antara kelompok siswa yang mengikuti pembelajaran menggunakan model pembelajaran treffinger berpendekatan saintifik dan kelompok siswa yang mengikuti pembelajaran konvensional.

\section{HASIL DAN PEMBAHASAN}

Rekapitulasi hasil perhitungana skor kemampuan berpikir kreatif, terdapat dapat tabel 1

Tabel 1. Deskripsi Data Hasil Penelitian

\begin{tabular}{lrrrrrr}
\hline \multirow{2}{*}{ Statistik } & \multicolumn{7}{c}{ Data } \\
\cline { 2 - 7 } $\mathrm{N}$ & \multicolumn{1}{c}{ A1 } & A2 & A1B1 & A1B2 & A2B1 & \multicolumn{1}{c}{ A2B2 } \\
\hline Mean & \multicolumn{1}{c}{34} & 17 & 17 & 17 & \multicolumn{1}{c}{17} \\
\hline Median & 136,12 & 127,15 & 140,71 & 131,53 & 118,06 & 136,24 \\
\hline Modus & 135,50 & 128 & 139 & 131 & 118 & 136 \\
\hline Standar Deviasi (SD) & 137 & 122 & 137 & 127 & 122 & 134 \\
\hline Varians (S2) & 6,93 & 10,05 & 5,95 & 4,33 & 4,31 & 3,77 \\
\hline Jangkauan/ Rentangan & 47,99 & 100,98 & 35,47 & 18,76 & 18,56 & 14,19 \\
\hline Nilai Minimum (Xmin) & 27 & 32 & 20 & 16 & 15 & 13 \\
\hline Nilai Maksimum (Xmaks) & 125 & 111 & 132 & 125 & 111 & 130 \\
\hline & 152 & 143 & 152 & 141 & 126 & 143 \\
\hline
\end{tabular}


Berdasarkan tabel 1 deskripsi data yang disajikan pada penelitian ini terdiri dari enam kelompok data yaitu: (1) kemampuan berpikir kreatif kelompok eksperimen (A1) memiliki nilai mean 136,12. (2) kemampuan berpikir kreatif kelompok kontrol (A2) memiliki nilai mean 127,15. (3) kemampuan berpikir kreatif kelompok eksperimen dengan gaya kognitif $F I$ (A1B1) memiliki nilai mean 140,71. (4) kemampuan berpikir kreatif kelompok eksperimen dengan gaya kognitif $F D$ (A1B2) memiliki nilai mean 131,53, (5) kemampuan berpikir kreatif kelompok kontrol dengan gaya kognitif $\mathrm{FI}$ (A2B1) memiliki nilai mean 118,06. dan (6) kemampuan berpikir kreatif kelompok kontrol dengan gaya kognitif $F D$ (A2B2) memiliki nilai mean 136,24..

Analisi data hipotesis pertama dan kedua dianalisis menggunakan uji ANAVA dua jalan menunjkan hasil yang disajikan pada tabel 2 berikut.

Tabel 2 Hasil Analisis Data Uji Hipotesis Pertama dan Kedua.

\begin{tabular}{lrrrrr}
\hline \multicolumn{1}{c}{ SV } & \multicolumn{1}{c}{ JK } & Df & \multicolumn{1}{c}{ RJK } & \multicolumn{1}{c}{ F } & \multicolumn{1}{c}{ Sig. } \\
\hline Intercept & 1178241,19 & 1 & 1178241,19 & 54181,17 & .000 \\
\hline Model & 1368.01 & 1 & 1368.01 & 62.9 & .000 \\
\hline Gaya Kognitif & 344,25 & 1 & 344,25 & 15,83 & .000 \\
\hline Model ${ }^{*}$ Gaya Kognitif & 3179.78 & 1 & 3179.78 & 146.22 & .000 \\
\hline Dalam & 1391.76 & 64 & 21.75 & & \\
\hline Total & 1184525 & 68 & & & \\
\hline
\end{tabular}

Berdasarkan tabel 2 uji hipotesis pertama menunjukkan bahwa hasil ANAVA dua jalan dengan $F$ hitung sebesar 62,9 dengan signifikansi $0,000<0,05$ sehingga $\mathrm{H}_{0}$ ditolak dan $\mathrm{H}_{1}$ diterima. Hal ini berarti terdapat perbedaan kemampuan berpikir kreatif antara siswa yang mengikuti pembelajaran dengan model pembelajaran treffinger berpendekatan saintifik dengan siswa yang mengikuti model pembelajaran konvensonal.

Hasil penghitungan menunjukan bahwa model pembelajaran treffinger berpendekatan saintifik lebih efektif meningkatkan kemampuan berpikir kreatif siswa di bandingkan dengan model pembelajaran konvensional. Hasil penelitian ini sejalan dengan penelitian Silfiana (2016) yang menunjukan bahwa pembelajaran dengan menggunakan model pembelajaran treffinger dengan pendekatan saintifik berkualitas baik untuk meningkatkan kemampuan berpikir kreatif siswa kelas V. Penelitian lainnya oleh Puspita (2018) dan Wardani (2017) menunjukan hasil kemampuan berpikir kreatif siswa yang menggunkan model pembelajaran treffinger lebih tinggi daripada siswa yang menggunakan model pembelajaran konvensional. Penelitian Maharani (2018) yang menujukan pelaksanaan pembelajaran dengan model pembelajaran treffinger dengan pendekatan saintifik terlaksana dengan baik.

Model pembelajaran treffinger berpendekatan saintifik memiliki tiga
tahap.Tahap basic tool terdiri dari pendekatan saintifik yang mencangkup kegiatan mengamati, menanya, mengumpulkan informasi, mengasosiasi, dan mengomunikasikan. Pada tahap siswa dapat berpikir secara divergen atau terbuka terlepas dari jawaban benar ataupun salah. Hal ini sejalan dengan pendapat Guiford (Purwaningrum, 2016) yang menjelaskan bahwa berpikir kreatif adalah proses berpikir menyebar (divergen) dengan menekankan berbagai jawaban dari permasalah yang dijumpai. Kemampuan berpikir kreatif yang berkembang pada tahap ini adalah kelancaran (fluency, berpikir luwes (flexibility) berpikir orisinal (originality), dan berpikir memerinci (elaboration). Tahap kedua practice with process terdiri dari pendekatan saintifik yang mencangkup kegiatan menanya, mengumpulkan informasi, mengasosiasi, dan mengomunikasikan. Pada tahap ini siswa diberikan permasalahan yang lebih kompleks dari permasalahan yang ada pada tahap basic tool, tahap kemampuan merangsang siswa untuk berpikir originality dan eloboration. Pada tahap terakhir working with real problems terdapat kegiatan saintifik mengumpulkan 
informasi, mengasosiasi dan mengomunukasikan. Pada tahap ini siswa dihadapkan pada soal-soal non rutin yang berhubungan dengan kehidupan seharihari sehingga siswa dituntut untuk memperoleh solusi dari permasalahan tersebut yang dapat merangsang kemampuan berpikir kreatif siswa pada aspek originality dan elaboration.

Berbeda halnya dengan model pembelajaran konvensional. Model pembelajaran ini tidak menantang siswa dalam berproses untuk memecahkan permasalahan nyata. Pembelajaran konvensional didominasi guru terhadap kelas dengan karakteristik menjelaskan pengertian serta konsep, memberi contoh, latihan dan pada akhirnya siswa diberikan soal untuk dikerjakan sebagai penerapan dari konsepkonsep yang telah diajarkan guru secara berkelompok.
Kemampuan berpikir kreatif siswa diduga dapat terjadi pada tahap kagiatan inti yaitu, saat guru menggali pengetahuan awal siswa dengan mengajukan pertanyaan-pertanyaan mengenai materi yang akan diberikan, kegiatan ini mampu mengembangakan kemampuan berpikir kreatif pada aspek fleuncy, siswa dapat tumbuh karena siswa menjawab pertanyaan yang diberikan guru (menanya) dan aspek eloboration pada saat siswa menyimpulkan semua materi pembelajaran di kelas (mengumpulkan informasi)

Berdasarkan tabel 2 uji hipotesis kedua menunjukan $\mathrm{F}$ hitung sebesar 146,22 dengan signifikansi $0,000<0,05$, sehingga $\mathrm{H}_{0}$ ditolak dan $\mathrm{H}_{1}$ diterima. Hal ini menunjukkan terdapat interaksi antara model pembelajaran dan gaya kognitif terhadap kemampuan berpikir kreatif siswa. Interaksinya terlihat pada gambar 1 .

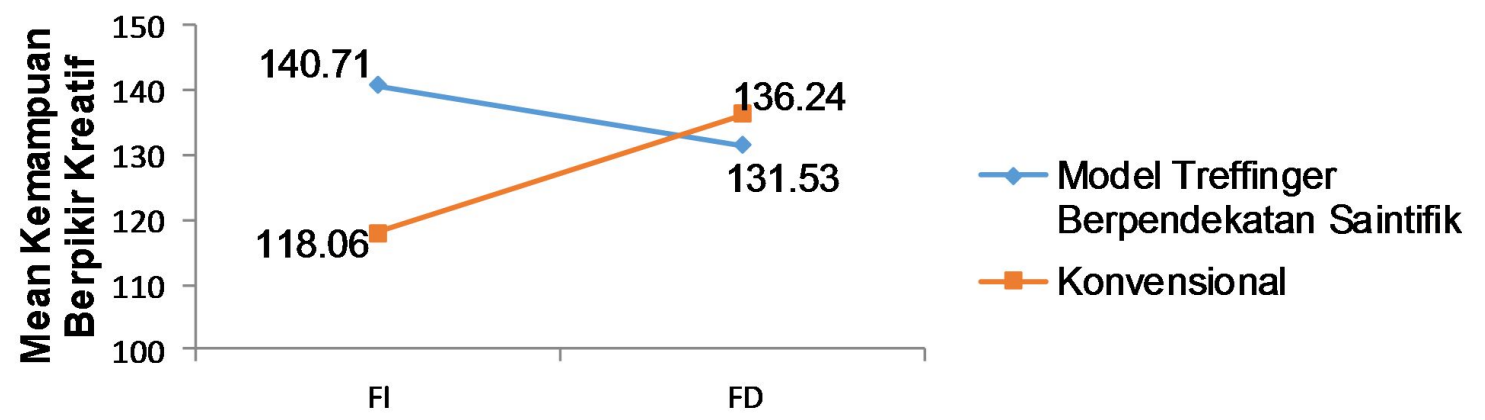

Gaya Kognitif

Berdasarkan gambar 1, terlihat bahawa siswa dengan gaya kognitif $F I$ memiliki skor kemampuan berpikir kreatif kreatif lebih tinggi saat mengikuti model pembelajaran treffinger berpendekatan saintifik, sedangkan untuk siswa yang memiliki gaya kognitif $F D$ memiliki skor kemampuan berpikir kreatif kreatif lebih tinggi saat mengikuti model pembelajaran konvensional. Hasil penelitian ini sejalan dengan penelitian Sudarman (2016) menunjukkan hasil belajar Matematika dengan model Problem Solving pada siswa yang belajar dengan bidang gaya kognitif mandiri $F I$ lebih baik daripada gaya kognitif $F D$. Penelitian lainya yaitu penelitian Mayasari (2014) menunjukkan siswa dengan gaya kognitif $F I$ hasil belajanya lebih tinggi saat mengikuti model pembelajaran berdasarkan maslah dan siswa dengan gaya kognitif $F D$ hasil belajarnya lebih tinggi saat mengikuti model pembelajaran konvensional.
Hal ini tentu tidak lepas dari beberapa faktor yan.g memengaruhi kemampuan berpikir kreatif yaitu faktor internal dan eksternal. Faktor internal yang memengaruhi kemampuan berpikir kreatif siswa, salah satu diantaranya gaya kognitif, sedangkan faktor eksternal salah satunya adalah model pembelajaran

Pada sisi faktor eksternal yakni model pembelajaran yang mendukung proses pembelajaran ke arah yang lebih baik. Model pembelajaran yang dapat membangun kemampuan berpikir kreatif anak salah satunya adalah model pembelajaran treffinger berpedekatan saintifik. Model ini terdiri dari tiga tahap yaitu tahap basic tool, tahap practice with process, tahap working with real problems. Pada setiap tahap terdapat kegiatan pada 
pendekatan saintifik. Selain model tersebut juga terdapat model konvensional. Model pembelajaran dan gaya kognitif memiliki interaksi dengan kemampuan berpikir kreatif, apabila pada siswa dengan gaya kognitif $F I$ memiliki kemampuan berpikir kreatif yang lebih jika mengikuti model pembelajaran treffinger berpendekatan saintifik dari pada siswa yang mengikuti pembelajaran konvensional. Hal ini karena siswa yang memiliki gaya kognitif $F I$ menunjukan sikap yang aktif dalam berpikir secara sesuatu mendetail untuk dapat menyelesaikan dan menemukan solusi dari permasalahan yang dihadapi. Hal sejalan dengan pendapat Slemanto (2003) yang memaparkan bahwa seorang dengan $\mathrm{Fl}$ cenderung menyatakan sesuatu gambaran lepas dari latar belakang gambaran tersebut, serta mampu membedakan objek-objek dari konteks sekitarnya dengan lebih mudah.

Berbeda halnya dengan pembelajaran konvensional yang lebih didominasi oleh aktivitas guru di kelas, mulai dari kegiatan awal sampai mengakhiri pembelajaran. Siswa mengikuti dengan teliti tahapan-tahapan proses pembelajaran tanpa berusaha memperdalam materi yang dipelajari, sehingga siswa yang memiliki gaya kognitif $F D$, lebih cocok diterapkan pembelajaran konvensional, karena siswa yang memiliki memiliki gaya kognitif $F D$ sudah terbiasa belajar dengan mengikuti semua yang dijelaskan secara rinci oleh guru. Hal ini didukung oleh penyatan Uchu (dalam Uno, 2012) yang menyatakan siswa yang memiliki gaya kognitif $F D$, umumnya akan mencatat berbagai nateri yang disampaikan tanpa memilah materi yang penting dan kurang penting. Siswa yang memiliki memiliki gaya kognitif $F D$ tidak memiliki upaya untuk belajar mandiri menambah pengetahuan baik melalui bertanya pada teman maupun membaca. Oleh karena itu, dibutuhkan peranan guru yang tinggi untuk memotivasi siswa dalam proses pembelajaran matematika pada siswa yang memiliki memiliki gaya kognitif $F D$.

Hipotesis ketiga dianalisis menggunakan uji tukey. Hasil penghitungan terdapat pada tabel 3 .

Tabel 3 Hasil Analisis Hipotesis Ketiga

\begin{tabular}{|c|c|c|c|c|}
\hline Model Pembelajaran & $\begin{array}{c}\text { Treffinger Berpendekatan } \\
\text { Saintifik }\left(A_{1} B_{1}\right) \\
\end{array}$ & $\begin{array}{l}\text { Konvensio } \\
\text { nal }\left(A_{2} B_{1}\right)\end{array}$ & $t_{\text {hitung }}$ & ttabel \\
\hline Rata-rata & 140,71 & 118,06 & & \\
\hline $\mathrm{RJK}_{\mathrm{D}}$ & 21,746 & & 22,65 & 1,997 \\
\hline $\mathrm{Dk}$ & 64 & & & \\
\hline
\end{tabular}

Berdasarkan tabel 3 siswa dengan gaya kognitif $F I$ pada kelompok eksperimen $\left(A_{1} B_{1}\right)$ skor rata-ratanya 140,71 dan pada kelompok kontrol $\left(\mathrm{A}_{2} \mathrm{~B}_{1}\right)$ skor rata-ratanya 118,06 dengan (RJK $\left.{ }_{D}\right)$ 21,746. Hasil penghitungan menunjukan thitung $=22,65>$ tabel dengan taraf signifikansi 0,05 sebesar 1,997, sehingga $\mathrm{H}_{0}$ diterima dan $\mathrm{H}_{1}$ ditolak. Hal ini menunjukan pada siswa yang memiliki gaya kognitif $\mathrm{Fl}$, terdapat perbedaan kemampuan berpikir kreatif siswa yang mengikuti pembelajaran dengan model pembelajaran treffinger berpendekatan saintifik dan siswa yang mengikuti pembelajran dengan model pembelajaran konvensional.

Siswa dengan gaya kognitif $\mathrm{Fl}$ memerlukan aktivitas penyelesain masalah yang kompleks, aktif, realistis, kontekstual, serta konkret dalam menyelesaikan permasalahan. Siswa dengan gaya kognitif $\mathrm{Fl}$ memiliki rasa ingin tahu yang tinggi sehingga siswa $\mathrm{FI}$ berpikir secara analitis dan sistematis terhadap suatu masalah yang dihadapi guna untuk menemukan solusi yang beragam untuk menyelesaikan permasalahan tersebut. Hal ini sesuai dengan karakteristik siswa $\mathrm{Fl}$ yang diungkapkan oleh Uchu (dalam Halimah,2014) yang mengemukan bahwa siswa dengan gaya kognitif $\mathrm{FI}$ menerima materi secara analisis, tertarik pada 
konsep-konsep baru untuk kepentingan sendiri, dan membuat suatu perbedaan konsep tertentu, serta aktif menggunakan pendekatan pengetesan hipotesis, dan inkuiri dalam pencapaian konsep.

Tahapan pembelajaran dengan model pembelajaran treffinger berpendekatan saintifik berperan positif dan sangat mendukung dalam pencapaian kemampuan berpikir kreatif yang optimal. Pad setiap tahap model pembelajaran treffinger berpendekatan saintifik terdapat permasalahan yang diselesaikan mulai dari masalah yang sederhana sampai dengan masalah yang kompleks. Hal ini merangsang siswa dengan gaya kognitif $F I$ menganalisis permasalahan yang dihadapi dengan sistematis menggunakan pendekatan saintifik untuk menemukan konsepkonsep baru guna menemukan solusi dari permasalahan yang dihadapi.

Pada sisi lain pembelajaran dengan model pembelajaran konvensional tidak memberi ruang bagi siswa yang memiliki gaya kognitif FI dalam terlibat aktif pada proses pembelajaran. Pada pembelajaran konvensional guru lebih banyak mengajarkan konsep-konsep bukan kompetensi yang tujuannya adalah siswa mengetahui sesuatu bukan untuk melakukan sesuatu. Siswa hanya pasif menerima, sementara guru mondominasi proses pembelajaran dengan berperan sebagai pentransfer ilmu. Berdasarkan penjabaran tersebut siswa yang memiliki gaya kognitif $\mathrm{Fl}$ cocok untuk mengikuti pembelajaran menggunakan model pembelajaran treffinger berpendekatan saintifik.

Hipotesis keempat dianalisis menggunakan uji tukey. Hasil penghitungan terdapat pada tabel 4 .

Tabel 4 Hasil Analsis Hipotesis Keempat

\begin{tabular}{|c|c|c|c|c|}
\hline Model Pembelajaran & $\begin{array}{c}\text { Treffinger } \\
\text { Berpendekatan Saintifik } \\
\left(\mathrm{A}_{1} \mathrm{~B}_{2}\right)\end{array}$ & $\begin{array}{l}\text { Konvensional } \\
\qquad\left(A_{2} B_{2}\right)\end{array}$ & $t_{\text {hitung }}$ & $t_{\text {tabel }}$ \\
\hline Rata-rata & 131,53 & 136,24 & & \\
\hline $\mathrm{RJK}_{\mathrm{D}}$ & \multicolumn{2}{|l|}{21,746} & 2,94 & 1,997 \\
\hline Dk & \multicolumn{2}{|l|}{64} & & \\
\hline
\end{tabular}

Berdasarkan tabel 4 siswa dengan gaya kognitif $F D$ pada kelompok eksperimen $\left(\mathrm{A}_{1} \mathrm{~B}_{2}\right)$ skor rata-ratanya 131,53 dan pada kelompok kontrol $\left(A_{2} B_{2}\right)$ skor rata-ratanya 136,24 dengan (RJK $\left.\mathrm{D}_{\mathrm{D}}\right) 21,746$. Hasil penghitungan menunjukan $t_{\text {hitung }}=2,94>t_{\text {tabel }}$ dengan taraf signifikansi 0,05 sebesar 1,997 , sehingga $H_{0}$ diterima dan $H_{1}$ ditolak. Hal ini menunjukan pada siswa yang memiliki gaya kognitif $F D$, terdapat perbedaan kemampuan berpikir kreatif siswa yang mengikuti pembelajaran dengan model pembelajaran treffinger berpendekatan saintifik dan siswa yang mengikuti pembelajran dengan model pembelajaran konvensional.

Perbedaan kemampuan berpikir kreatif antara siswa yang mengikuti pembelajaran dengan model pembelajaran treffinger berpendekatan saintifik dengan siswa yang mengikuti pembelajaran konvensional.
Tahapan pada model pembelajaran treffinger berpendekatan saintifik berperan positif dan sangat mendukung dalam pencapaian kemampuan berpikir kreatif yang optimal. Namun, hal ini tidak berlaku bagi siswa yang memiliki gaya kognitif $F D$. Siswa $F D$ cenderung pasif sehingga keberhasilan belajar cenderung rendah. Hal ini didukung oleh penyataan Uchu (dalam Uno, 2012) yang menyatakan siswa yang memiliki gaya kognitif $F D$ cenderung pasif, menggunakan penontonan (ekspositori, ceramah, dan demonstrasi) untuk mencapai konsep

Penerapan model pembelajaran treffinger berpendekatan saintifik pada siswa yang memiliki gaya kognitif $F D$ 
mengakibatkan pembelajaran tidak berlangsung efektif. Hal ini karena siswa dengan gaya kognitif $F D$ akan mengalami kesulitan pada tiap tahap dalam pembelajaran dengan model treffinger berpendekatan saintifik mulai tahap basic tool, tahap practice with process, dan tahap working with real problems. Ketiga tahap ini menutut siswa untuk berpikir secara sistematis dan mandiri, sementara itu siswa $F D$ cenderung menerima informasi melalui hafalan. Siswa yang memiliki gaya kognitif $F D$ memerlukan tujuan pembelajaran yang tersusun baik. Slemanto (2003) yang menyatakan siswa yang memiliki gaya kognitif $F D$ di dalam memberikan jawabanya bergantung pada pujian yang diberikan guru. Melalui interaksi siswa dengan gaya kognitif $F D$ guru memiliki kesempatan memengaruhi secara kuat proses belajar dan tingkah laku siswa.

Pada siswa yang memiliki gaya kognitif $F D$ diterapkan pembelajaran konvensional, siswa merasa dibantu dan dibimbing dalam menyelesaikan permasalahan yang dihadapi. Penjelasan guru secara maksimal disimak oleh siswa. Dalam pembelajaran, siswa selalu dibimbing guru dan tidak mempunyai kepercayaan diri untuk menyampaikan pendapat. Siswa yang mempunyai gaya kognitif $F D$ lebih membutuhkan perhatian guru, harus selalu diingatkan untuk memperhatikan yang sedang dijelaskan. Dengan demikian, pembelajaran konvensional lebih bermakna untuk diterapkan pada siswa yang memiliki gaya kognitif $F D$.

\section{PENUTUP}

Berdasarkan analisis data yang telah dipaparkan, maka diperoleh temuan sebagai berikut. Pertama, terdapat perbedaan kemampuan berpikir kreatif antara siswa yang mengikuti pembelajaran model treffinger berpendekatan saintifik dengan siswa yang mengikuti pembelajaran model konvensional. Kedua, pada siswa yang memiliki gaya kognitif $\mathrm{Fl}$ terdapat interaksi antara model pembelajaran dan gaya kognitif terhadap kemampuan berpikir kreatif. Ketiga, terdapat perbedaan kemampuan berpikir kreatif antara siswa yang mengikuti pembelajaran model treffinger berpendektan saintifik dengan siswa yang mengikuti pembelajaran model konvensional. Keempat, pada siswa yang memiliki gaya kognitif $F D$ terdapat perbedaan kemampuan berpikir kreatif antara siswa yang mengikuti pembelajaran model treffinger berpendekatan saintifk dengan siswa yang mengikuti pembelajaran model konvensional.

Berdasarkan temuan dalam penelitian ini, maka diajukan beberapa saran sebagai berikut. Pertama, guru disarankan menerapkanmodel treffinger berpendekatan saintifik untuk mengoptimalkan kemampuan berpikir kreatif siswa. Kedua, peneliti yang tertarik melakukan penelitian sejenis, agar meneliti aspek atau variabel lain yang diduga memiliki kontribusi terhadap konsepkonsep dan teori-teori tentang pembelajaran yang kiranya dapat dipecahkan dengan menggunakan model treffinger dengan pendekatan saintik

\section{DAFTAR RUJUKAN}

Alfiyanti, D. 2016. "Pengaruh Model Pembelajaran Treffinger Terhadap Kreativitas Matematika Siswa Kelas VII SMP Negeri 1 Poncowarno" Tersedia pada http://ejournal.umpwr.ac.id/index.ph p/ekuivalen/article/view/3071/0. Diakses pada tanggal 08 Nopember 2018.

Boesen, J. 2006. "Department of Mathematics and Mathematical Statistic Ume University". Assessing Mathematical Creativity. Doctoral Thesis. No 34.

Dantes, N. 2012. Metode Penelitian. Yogyakarta: C.V Andi Offset. 
Inayah, N. 2016. "Pengaruh Kemampuan Penalaran Matematika dan Gaya Kognitif Terhadap Kemampuan Komunikasi dan Koneksi pada materi Statistika Siswa SMA". Jurnal Of EST. Volume 2 No 2.

Maharani, R.K. 2018. "Pengaruh Model Pembelajaran Treffinger Terhadap Kemampuan Berpikir Kreatif Pelajaran Matematika Materi Bangun Ruang."JPSD. Vol 06 No 4 hal 506-515.

Mayasari, N M D 2014. "Pengaruh Model Pembelajaran Berbasis Masalah Terhadap Hasil Belajar Matematika Ditinjau dari Gaya Kognitif Siswa Kelas V Sd di Gugus II Kecamatan Mengwi". e-Journal Program Pascasarjana Universitas Pendidikan Ganesha Program Studi Pendidikan Dasar (Volume 4 Tahun 2014) Tersedia pada http://pasca.undiksha.ac.id. Diakses pada 08 Nopember 2018

Munandar, U. 2004. Pengembangan Kreativitas Anak Berbakat. Jakarta: Rineka Cipta.

Murtiyasa, B. 2015. "Tantangan Pembelajaran Matematika Era Global". Jurnal Universitas Muhammadiah Surakarta. Vol 1 hal.1.

Novitayanti, N.P.E. 2016. "Pengaruh Model Pembelajaran Kooperatif Tipe TGT (Team Games Tournament) dan Gaya kognitif terhadap prestasi belajar TIK Siswa Kelas VIII SMP Negeri 1 Nusa Penida". Tesis (tidak diterbitkan). Program Studi Teknologi Pembelajaran, Program Pascasarjana, Universitas Pendidikan Ganesha, Singaraja.

$\begin{array}{cr}\text { Purwaningrum, J.P. } & 2016 . \\ \text { "Mengembangkan } & \text { Kemampuan }\end{array}$ "Mengembangkan Kemampuan
Berpikir Kreatif Matematis Melalui
Discovery Learning Berbasis Scientific Approcach". Jurnal Refleksi Edukatika. Vol 6 No 2 Hal 145-157

Puspita, M. 2018. Pengaruh Model Pembelajaran Treffinger Untuk Pokok Bahasan Bunyi Terhadap Motivasi Belajar dan Kemampuan Berpikir Kreatif. Tersedia pada http://ejournal.umpwr.ac.id. Diakses pada p 08 Nopember 2018.

Ramandhani, D dan Nuryanis. 2017. "Analisis Kemampuan Berpikir Kreatif Matematis Siswa SD di Kecamatan Langsa Lama". PROSIDING SEMINAR NASIONAL MIPA III. Langsa-Aceh, 30 Oktober 2017 ISBN 978-602-50939-0-6.

Sudarman, et al. 2016. "The Effect of Learning Strategy and Cognitive Style toward Mathematical Problem Solving Learning Outcomes". IOSR Journal of Research \& Method in Education (IOSR-JRME). Vol.6, Issue 3. Tersedia pada http://www"'.'iosrjournals.org/iosrirme/papers/Vol-6\%20lssue-3/ Version-4/V060304137143.pdf. Diakses pada 08 Nopember 2018.

Silfiana, I dkk. 2016. "Model Treffinger dengan Pendekatan Saintifik untuk Meningkatkan Kemampuan Berpikir Kreatif Dalam Memecahkan Masalah siswa Kelas V". Jaurnal of Primery Education.JPE 5 (2) 2016.

Slameto. 2003. Belajar dan Faktor-faktor Yang Mempengaruhi. Jakarta: Rineka Cipta.

Uno, H B. 2012.Orientasi Baru dalam Psikologi Pembelajaran.Jakarta:PT Bumi Aksara

Wardani, R.W. 2017. "Pengaruh Model Treffinger dengan Pendekatan Saintifik untuk Meningkatkan Kemampuan Komunikasi Matematis Tertulis Siswa SMKN 2 Kediri Kelas IX Pokok Bahasan Relasi dan 
Vol.1 No 1, Pebruari 2017

ISSN: 2613-9553

Fungsi”. Tersedia pada http://repository.ump.ac.id. Diakses pada 08 Nopember 2018 